\title{
The opportunities for obtaining of the biogas on methane fermentation from marine algae biomass and water plant biomass
}

\author{
Ewa Jachniak ${ }^{1, *}$, Joanna Chmura $^{2}$, Mariusz Kuglarz ${ }^{1}$, Józef Wiktor $^{3}$ \\ ${ }^{1}$ Institute of Environmental Protection and Engineering, University of Bielsko-Biala, Poland \\ ${ }^{2}$ Student ofthe Environmental Engineering, University of Bielsko-Biala, Poland \\ ${ }^{3}$ Institute of Oceanology of the Polish Academy of Sciences in Sopot
}

\begin{abstract}
The aim of the research was to try to obtain of the biogas on a laboratory scale from marine algae biomass and water plant biomass. The research was conducted in 2016 year and samples were taken from the Polish coast of the Baltic Sea. In laboratory work, algae and plant species were first identified. The next, in order to subject them to methane fermentation processes and to obtain biogas,partial mechanical treatment of the biomass was conducted. Dry matter content and dry organic matter content were also determined. The research has shown different production of the biogas depending on the various species of the algae and plants. The percentage composition of the biogas was also determined $\left(\% \mathrm{CO}_{2}\right.$ and $\left.\% \mathrm{CH}_{4}\right)$. In this research some kinds and species of algae and aquatic plants were distinguished: Scytosiphon cf. S. tortilis, Fucus vesiculosus, Cladophora, Audouinella, Potamogeton perfoliatus. Production of biogas from selected algae and water plants oscillated between $0.023 \mathrm{dm}^{3} \cdot \mathrm{g}^{-1}$ and $0.303 \mathrm{dm}^{3} \cdot \mathrm{g}^{-1}$. The highest content of the methane in biogas was obtained from the mixture of Ectocarpus from spring and autumn harvest (values oscillated from $80.7 \%$ to $81.2 \%$ ), while the highest percentage share of carbon dioxide in the biogas was characterized by the mixture Fucus vesiculosus and Audouinella (22\%). Due to a small amount of the research in this field, more research is needed.
\end{abstract}

\section{Introduction}

The marine and freshwater algae are used extensively for economic, consumer and industrial purposes i.e. Their role in the human economy is extremely large (in food industry and biofuels) [1,2,3]. In coastal areas algae are thrown ashore by the waves and are used as animal feed or fertilizer, because they contain lots of microelements and vitamins. Recently, much attention has been paid to the use of algae biomass as a potential source of renewable energy. There are many studies on the use of algae for the production of biogas, bioethanol and biooil all over the world $[1,2,3,4,5$, 6]. Algae have this advantage that they grow fast and they can double their biomass within 24 hours, with enough amount of the light, $\mathrm{CO}_{2}$ and mineral salts (mainly inorganic nitrogen and phosphorus compounds) [7].

Currently, much attention has been paid to the use of the water vascular plants biomass for energy purposes, i.e. Lemna minor, Lemna trisulica, Potamogeton perfoliatus, Myriophyllum aquaticum and Egeria densa [3, 8]. The most popular is Lemna, because it grows fast (like algae) and its mass doubles every 1-3 days. It can also be easily collected from the surface of the freshwater reservoirs [3].

Excessive growth of algae is very unfavorable to the aquatic environment, because it disturbs its ecological balance. Nowadays the algae blooms are often happens, they arise as a result of the excessive discharge of the municipal and industrial wastewater and inappropriate farming economy. Algae blooms are observed in many water reservoirs, as well as in the Baltic Sea. They cause the water to become unfit for utility purposes (consumer and recreational), the aesthetic properties are also deteriorated. Algae blooms are a symptom of eutrophication of the water reservoirs and they carry many negative consequences, i. a. change in organoleptic properties of the water (taste, smell and colour), oxygen deficiency, death of the aquatic animals and plants, secretion of the toxins into the water by some cyanobacteria.These toxins are very dangerous for animals and human health $[5,9,10,11$, $12,13]$.

In the Baltic Sea,increased algae blooms are seen mainly in the Gulf of Gdańsk and in the east and southeast coast of Sweden. The Baltic Sea is an enclosed sea, characterized by a very large catchment area (1 $\left.729000 \mathrm{~km}^{2}\right)$, of very intensively developed agriculture, inhabited by about 80 million people [14].

\footnotetext{
Corresponding author: ejachniak@ath.bielsko.pl
} 
All of these factors significantly leads to its eutrophication. The topic of eutrophication of the Baltic Sea was discussed by many authors, i.e. Wasmund 2002, Bień et al. 2010, Håkanson, Bryhn 2011, Leśniewska, Witak 2011, Michalak et al. 2016.

Many different methods are used to moderate the eutrophication of the Baltic Sea (construction of various sewage treatment plants, also home sewage treatment plants, construction and reconstruction of the small water retention). The surplus of the algae biomass can be used to reduce of eutrophication. A good way can be to collect algae from the beach and use for different purposes, i.e. for the biogas or bioethanol production. There are a variety of techniques to harvest of the excess algae from the sea, which are constantly being improved. Magnetite particles are often used and special nets are applied [3].

Water plants often overgrow large fragments of the water reservoirs and therefore their biomass can be used for energy purposes (f. e. biogas and biooil production) $[3,8,15]$.

The aim of this research was to try to obtain biogas on a laboratory scale from selected marine algae biomass and aquatic plants biomass as a result of methane fermentation.

\section{Methodology of research}

The samples of selected algae and aquatic plants were collected from several points located at the Polish coast of the Baltic Sea (Fig. 1) in the period from May to September 2016. The Baltic Sea is an inland sea, which is located in the northern part of Europe. This sea connects with the North Sea through the Danish strait (f. e. Skagerrak and Kattegat).This sea is exposed to large amounts of the biogenic compounds, because it has a large catchment area. The biogenic substances are the main nutrients for algae. It causes that algae develop in excess and often create algae blooms [14, 16]. Algae blooms are most often observed in the coastal part of the Gulf of Gdańsk, so it was decided to collect samples from this part of the Baltic Sea in most terms (in May, July and September). The samples of the algae and water plants were collected in 12 May and 13 September from the beach in Brzeźno (northern district of Gdańsk), while 16 July from the beach in Mikoszewo (on the east of Gdańsk). In turn, in August, the samples were taken from Slowińskie Coast (26 August from the beach in Ustka and 29 August from the beach in Poddąbie) (Fig. 1).

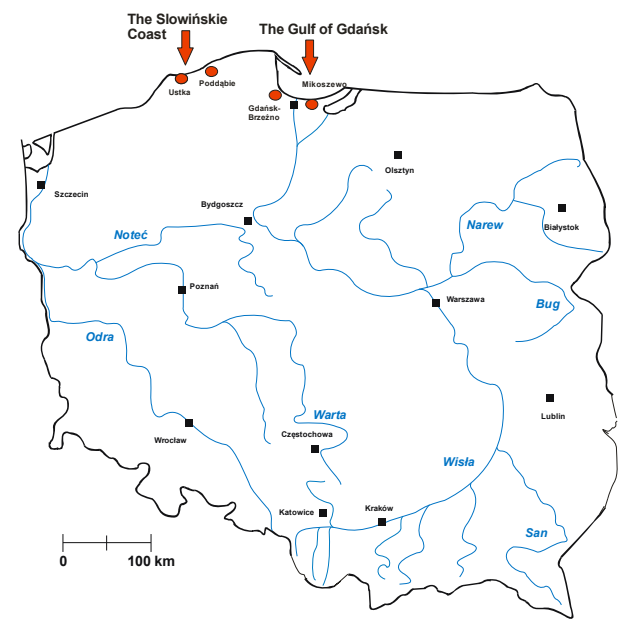

Fig. 1. The map of Poland and the places for taking samples $[17$, it was modified $]$

The collected samples were transported to ATH in Bielsko-Biala, where they were rinsed with tap water from sand and other contaminants and put on the tissue-paper to remove excess of the water and partial dry (for about 1 hour). After that, they were weighed, determined the species level, described and frozen. The analysis of the species composition of the collected algae and plants were conducted NIKON ECLIPSE E200 microscope equipped with Delta Pix Invenio digital camera and digital image analysis software.

The key to identification of the macrophytes was done with help of identification key [18]. Additionally, the web pages of the Institute of Oceanography of the University of Gdansk were also used:

http://www.hel.univ.gda.pl/atlas/organizmy.htm, http://www.hel.univ.gda.pl/. There was also used from the web page of theCultureCollection of Baltic Algae of the Institute of Oceanography of the University of Gdansk:

http://ccba.ug.edu.pl/pages/pl/strona-glowna.php. In addition, some species designations were consulted with Professor Józef Wiktor from the Institute of Oceanology of the Polish Academy of Sciences in Sopot.

\subsection{Determination of the dry matter and dry organic matter}

Dry matter and dry organic matter measurements were carried out in accordance with Polish norms PN-EN 12880 and PN-EN 12879.The algae and water plants samples intended for the biogas production were fragmented into smaller parts (about $1 \mathrm{~cm}$ long) and then were weighed on an analytical balance with accuracy to $0.001 \mathrm{~g}$. These samples were dried in ceramic evaporating dish in an electric oven for 4 hours at temperature of about $105{ }^{\circ} \mathrm{C}$. After this time, evaporating dish with dried material was again weighed.Subsequently the samples were burn in a muffle furnace for 2 hoursat the temperature of about $550{ }^{\circ} \mathrm{C}$ and then evaporating dish with mineral residue was again weighed also with accuracy to $0.001 \mathrm{~g}$. 


\subsection{Initial mechanical pretreatment of the substrates for the fermentation process}

Initial mechanical pretreatment is carried out to provide better conditions for the work of anaerobic bacteria in the fermentation process. This is necessary, because cell walls of the algae and plants are poorly degradable (their main ingredient is cellulose) and it causes many obstacles in the work of the bacteria. The initial preparation of the collected samples for biogas production was done according method published in [5, $6,19,20]$. In order to prepare algae and aquatic plants samples for fermentation, the frozen samples were thawed and then they were mechanically processed. Mechanical treatment consisted of cutting this material into lengths of $1 \mathrm{~cm}$ or smaller. Then the cut material was rubbed in a mortar to obtain pulp. The individual types and species of algae and plants were subjected to the mechanical pretreatment.

In each case $2 \mathrm{~g} / \mathrm{dm}^{3}$ of substrates used were added to the bioreactor. Assays for determination of practical methane potential of algae and aquatic biomass were carried out in $1.5 \mathrm{dm}^{3}$ bioreactors with working volume of $1 \mathrm{dm}^{3}$. After addition substrates to bioreactors 200 $\mathrm{cm}^{3}$ of the distilled water, minus the volume of the substrates was added. In each case, methanogenic inoculum $\left(800 \mathrm{~cm}^{3}\right)$, transported from Aqua S.A. Sewage Treatment Plant in Komorowice in BielskoBiala, were added to the bioreactors. Basic anaerobic media (BA) [21] were added to each bioreaktor. The bioreactors were sealed with butyl rubber stoppers and aluminum crimps and then purged with a mixture of $\mathrm{CO}_{2}$ and $\mathrm{N}_{2}(20 / 80 \%)$. The assays were undergoing digestion at $55^{\circ} \mathrm{C}$, until no significant amounts of $\mathrm{CH}_{4}$ were produced (approx. 30 days). Every day, each bioreactor was mixed for about 60 seconds to ensure optimum conditions for the fermentation process. The amount of methane produced was expressed per unit of VS (d.o.m.) added. The amount of biogas produced by inocula (control vials without algae and plants) was subtracted from all tested assays. If the amounts of algae were insufficient for the fermentation process, they were used in the form of mixture (brown algae Fucus vesiculosus and red algae Audouinella).

\subsection{Measurement of the biogas and methane content}

The stand for biogas productionwas built of the equalizing reservoir and scaled reservoir. The scaled reservoir was filled with $5 \%$ sodium chloride. The both reservoirs were connected to each other and it caused the displacement of the surplus sodium chloride solution to the equalizing reservoir by forming fermentation gas. The volume of the biogas was converted to normal conditions, i.e. $0{ }^{\circ} \mathrm{C}$ and $1 \mathrm{~atm}$.

The obtained biogas was collected in special bags and methane content of the obtained biogas was analyzed by using the ENVAG portable meter of the biogas composition.
The obtained methane wasex pressed as a unit production of this gas in relation to the organic dry matter unit used. The amount of the obtained methane from the control sample was subtracted from all tested samples, which were subjected to the fermentation processes.

The methane yield was calculated based on the volume of the methane produced per unit mass of volatile solids used, according to the following formula:

$$
Y_{\mathrm{CH}_{4}}=\frac{\mathrm{CH}_{4} \text { obtained }}{\hbar \text { d.o.m. }}
$$

where:

- $Y_{\mathrm{CH}_{4}}$ - unit production of the methane [ $\mathrm{dm}^{3} \mathrm{CH}_{4} \cdot \mathrm{g}^{-1} \mathrm{VS}$ added]

- $\mathrm{CH}_{4}$ obtained - the amount of the methane produced in the analyzed time $\left[\mathrm{dm}^{3}\right]$

- $€$ d.o.m. - the amount of the grams VS added to the bioreactor during the process $[\mathrm{g}]$.

\section{Results}

In all collected samples the following groups, kinds and species of algae and aquatic plants were distinguished:

\section{a) brown algae}

[http://www.algaebase.org/search/species/detail/?specie s_id=291, 5]:

- Scytosiphon cf. S. tortilis - usually creates filamentous thallus with numerous lateral branches (phot. 1),

- Fucus vesiculosus - forms a ribboned and forked branched thallus, which has a numerous buoyant blisters,

- Ectocarpus - creates the brown filamentous and unbranched thallus,

b) green algae [22]:

- Cladophora - has filamentous thallus, which promotes the formation of the thick algae coat on the surface of the water (phot. 2),

c) red algae [23]:

- Audouinella -has a dark-reddish thallus, it creates dense and finely branched underwater turfs, which are sometimes visible on the water surface (phot. 3),

d)aquatic vascular plants [18]:

- Potamogeton perfoliatus - has a long stems, which can reach up to 6 meters in length. The rhizomes are durable and they have peak winter buds and the stem is flexible and strongly branched. 


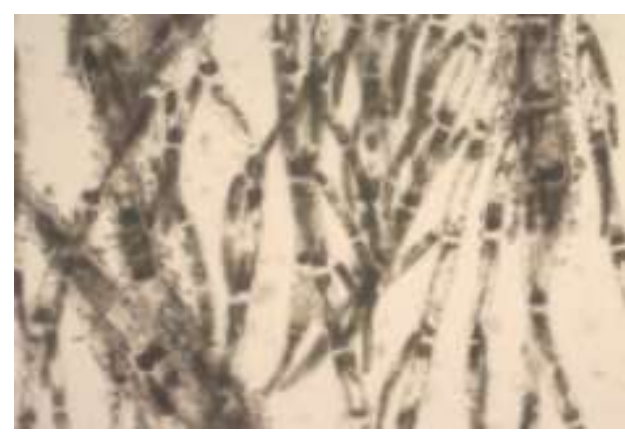

Phot. 1. Scitosiphon cf. S. tortilis visible under the microscope

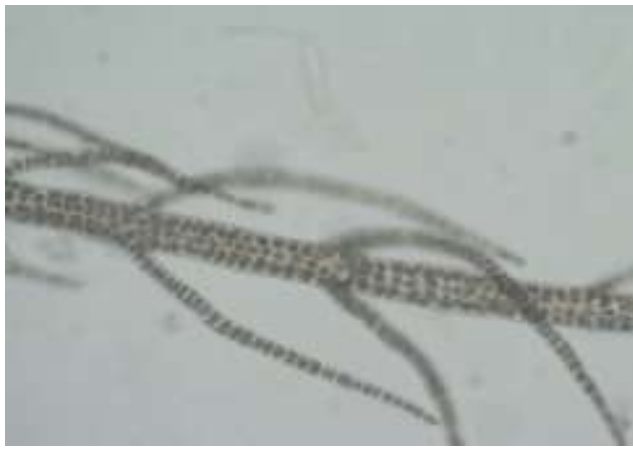

Phot. 2.Cladophora visible under the microscope

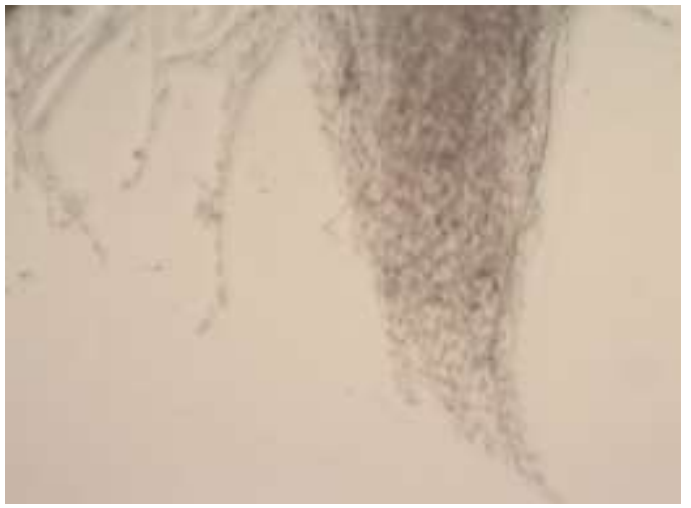

Phot. 3. Audouinella visible under the microscope

The content of the dry matter and dry organic matter of the identified algae and water plants is presented in below table (tab. 1).

Tab. 1. The content of the dry matter and dry organic matter in identified algae and water plants.

\begin{tabular}{|c|c|c|}
\hline The identified algae and plants & $\underset{\left(\mathrm{g} \cdot \mathrm{kg}^{-1}\right)}{\text { d.m. }}$ & $\begin{array}{l}\text { d.o.m. } \\
\left(\mathrm{g} \cdot \mathrm{kg}^{-1}\right)\end{array}$ \\
\hline Ectocarpus - collected in spring & 220.84 & 218.16 \\
\hline Scitosiphon cf. S. tortilis & 111.33 & 109.88 \\
\hline
\end{tabular}

\begin{tabular}{|c|c|c|}
\hline Potamogeton perfoliatus & 120.21 & 113.53 \\
\hline Fucus vesiculosus & 219.02 & 217.77 \\
\hline Cladophora & 255.08 & 253.95 \\
\hline Ectocarpus - collected in autumn & 186.65 & 185.82 \\
\hline Audouinella & 570.09 & 569.63 \\
\hline
\end{tabular}

The red algae Audouinella was characterized the highest content of the $\mathrm{d}$. $\mathrm{m}$. and d. o. m.(respectively $570.09 \mathrm{~g} \cdot \mathrm{kg}^{-1}$ and $\left.569.63 \mathrm{~g} \cdot \mathrm{kg}^{-1}\right)$. In turn, the brown algae Scitosiphon cf. $S$. tortilis contained the lowest content of the d. m. and d. o. m. (respectively $111.33 \mathrm{~g} \cdot \mathrm{kg}^{-1}$ and $109.88 \mathrm{~g} \cdot \mathrm{kg}^{-1}$ ).

The amount of the biomethane, obtained from selected algae and plants is presented in below table (tab. 2).

Tab. 2. The obtained amounts of methane from particular algae and aquatic plants.

\begin{tabular}{|c|c|}
\hline $\begin{array}{c}\text { The identified algae and } \\
\text { plants }\end{array}$ & $\begin{array}{c}\text { The obtained } \\
\text { amounts of } \\
\text { methane } \\
{\left[\mathrm{dm}^{3} \cdot \mathrm{g}^{-1}\right]}\end{array}$ \\
\hline $\begin{array}{c}\text { Ectocarpus - } \\
\text { collected in spring }\end{array}$ & 0.303 \\
\hline Scitosiphon cf. S. tortilis & 0.023 \\
\hline Potamogeton perfoliatus & 0.076 \\
\hline $\begin{array}{c}\text { The mixture of Fucus } \\
\text { vesiculosus } \\
\text { and Audouinella }\end{array}$ & 0.271 \\
\hline Cladophora & 0.198 \\
\hline $\begin{array}{c}\text { Ectocarpus - } \\
\text { collected in autumn }\end{array}$ & 0.172 \\
\hline Audouinella & - \\
\hline $\begin{array}{l}\text { The mixture of Ectocarpus - } \\
\text { from spring and autumn harvest }\end{array}$ & 0.240 \\
\hline
\end{tabular}

Production of biogas from selected algae and water plants oscillated between $0.023 \quad \mathrm{dm}^{3} \cdot \mathrm{g}^{-1}$ and $0.303 \mathrm{dm}^{3} \cdot \mathrm{g}^{-1}$. The lowest production of biomethane was found for brown algae Scitosiphon cf. $S$. tortilis, the value of this production achieved only 


\section{$0.023 \mathrm{dm}^{3} \cdot \mathrm{g}^{-1}$.}

In turn, the largest production was characterized by another brown algae - Ectocarpus from spring harvest.The value of the obtained methane was at the level of $0.303 \mathrm{dm}^{3} \cdot \mathrm{g}^{-1}$. Similarly, the high methane value was found when the mixture of these two brown algae (from spring and autumn harvest) was applied $\left(0.240 \mathrm{dm}^{3} \cdot \mathrm{g}^{-1}\right)$.

The red algae Audouinella was not able to produce biogas, but mixed with Fucus vesiculosus has allowed to obtain the biogas on a fairly high level of $0.271 \mathrm{dm}^{3} \cdot \mathrm{g}^{-1}$.

The percentage of the biogas obtained is shown in the table 3 .

Tab. 3. Percentage content of the methane and carbon dioxide in the obtained biogas.

\begin{tabular}{|c|c|c|c|}
\hline \multirow[t]{2}{*}{ Name of the substrate } & \multicolumn{2}{|c|}{$\begin{array}{c}\text { The content } \\
\text { of the } \\
\text { methan } \\
\text { (\% vol.) }\end{array}$} & \multirow{2}{*}{$\begin{array}{l}\text { The content of } \\
\text { the carbon } \\
\text { dioxide } \\
\text { (\% vol.) }\end{array}$} \\
\hline & $\min$ & $\max$ & \\
\hline $\begin{array}{l}\text { The mixture of the } \\
\text { Ectocarpus collected in } \\
\text { spring and autumn }\end{array}$ & 80.7 & 81.2 & 18.8 \\
\hline $\begin{array}{l}\text { The mixture of the } \\
\text { Fucus vesiculosus and } \\
\text { Audouinella }\end{array}$ & 73.0 & 75.1 & 22.0 \\
\hline Potamogeton perfoliatus & 69.9 & 70.9 & 17.2 \\
\hline $\begin{array}{l}\text { Ectocarpus - collected } \\
\text { in spring }\end{array}$ & 79.4 & 79.8 & 20.4 \\
\hline Cladophora & 73.3 & 73.3 & 12.8 \\
\hline
\end{tabular}

The highest content of the methane in biogas was obtained from the mixture of Ectocarpus from spring and autumn harvest (values oscillated from $80.7 \%$ to $81.2 \%$ ), while the minimum methane content was found in the biogas obtained from the Potamogeton perfoliatus (values oscillated from $69.9 \%$ to $70.9 \%$ ).

In turn, the highest percentage share of carbon dioxide in the biogas was characterized by the mixture Fucus vesiculosus and Audouinella (22\%), while the lowest carbon dioxide content was found in the biogas obtained from the Cladophora (12.8 \%).

From the Scitosiphon cf. S. tortilis wasn't read the composition of the obtained biogas, because there was too little biogas production. In turn, from the Ectocarpus collected in autumn wasn't also read the composition of the obtained biogas, because there were technical reasons.

\section{Discussion}

The influent of large amounts of the biogenic substances to the Baltic Sea causes increase its eutrophication and disturbs its ecological balance. Excessively growing algae often create of thick algae coat on the surface of the water. Algae blooms are especially visible at the edge of the sea, sometimes algae are thrown to the beach by the waves. Unfortunately, this greatly reduces the aesthetic and sanitary values of these places. Algae blooms also generate a threat to human health, therefore many different methods are used to eliminate algae from water reservoirs and Baltic Sea. Harvest of the algae from beaches and water for energy purposescould reduce their quantity in water and could improve the quality of Baltic Sea water [3, 5, 6, 16, 24].

The conducted research has shown, that the largest amount of the biogas was obtained from the biomass of the brown algae Ectocarpus, which was collected in spring $\left(0.303 \mathrm{dm}^{3} \cdot \mathrm{g}^{-1}\right)$. The mixture of two algae: Audouinella and Fucus vesiculosus has allowed to obtain less quantity of the biogas $\left(0.271 \mathrm{dm}^{3} \cdot \mathrm{g}^{-1}\right)$. Barbot et al. [5] obtained the less amount of the biogas from Fucus vesiculosus. Production of biogas from this algae oscillated between $0.04 \mathrm{dm}^{3} \cdot \mathrm{g}^{-1}$ do $0.11 \mathrm{dm}^{3} \cdot \mathrm{g}^{-1}$. In turn, the other authors Vivekanand et al. [19] found a little more of the biogas, which was produced from Saccharina latissima. The values oscillated between $0.22 \mathrm{dm}^{3} \cdot \mathrm{g}^{-1}$ and $0.26 \mathrm{dm}^{3} \cdot \mathrm{g}^{-1}$.

The presented research has revealed low value amount of the biogas $\left(0.076 \mathrm{dm}^{3} \cdot \mathrm{g}^{-1}\right)$ with the lowest methane content (from $69.9 \%$ to $70.9 \%$ ) in Potamogeton perfoliatus biomass. This amount of the obtained biogas was comparable with other aquatic plants (i. a. Elodea densa and Potamogeton malaianus). Koyama et al. [15] found the methane production on a slightly higher level of $0,16 \mathrm{dm}^{3} \cdot \mathrm{g}^{-1}$ and $0,36 \mathrm{dm}^{3} \cdot \mathrm{g}^{-1}$ during the 14 day fermentation process. In turn, Kesaano [25] was found that the percentage content of the methane in the obtained biogas from Lemna biomass reached the level between $67,1 \%$ and $68,63 \%$.The all authors used different pretreatment methods and depending on them they received different results.

Due to a small amount of the research in this field, more research is needed. The improvement of the technique of harvesting and initial pretreatment of the algae and water plants biomass is necessary. It would also be good to increase the number of studies on specific species and types of the algae and aquatic plants.

\section{Conclusions}

1. In all collected samples the following kinds and species of algae and aquatic plants were found: Scytosiphon cf. S. tortilis, Fucus vesiculosus, Cladophora, Audouinella, Potamogeton perfoliatus.

2. Production of biogas from selected algae and water plants oscillated between $0.023 \mathrm{dm}^{3} \cdot \mathrm{g}^{-1}$ and $0.303 \mathrm{dm}^{3} \cdot \mathrm{g}^{-1}$. The lowest production of biomethane was found for brown algae Scitosiphon cf. S. tortilis $\left(0.023 \mathrm{dm}^{3} \cdot \mathrm{g}^{-1}\right)$. The largest production of biomethane was 
characterized by another brown algae Ectocarpus from spring harvest $\left(0.303 \mathrm{dm}^{3} \cdot \mathrm{g}^{-1}\right)$ and by the mixture of these two brown algae (from spring and autumn harvest) $\left(0.240 \mathrm{dm}^{3} \cdot \mathrm{g}^{-1}\right)$.

3. The highest content of the methane in biogas was obtained from the mixture of Ectocarpus from spring and autumn harvest (values oscillated from $80.7 \%$ to $81.2 \%$ ). The minimum methane content was found in the biogas obtained from the Potamogeton perfoliatus (values oscillated from $69.9 \%$ to $70.9 \%$ )

\section{Acknowledgments}

I would like to thank the Professor Józef Wiktor from the Institute of Oceanology of the Polish Academy of Sciences in Sopot for help in identifying some species of algae.

\section{References}

1. A. Hossain, A. Salleh, Am. J. Biochem. Biotech. 4, (3) (2008)

2. M. Frąc, S. Jezierska-Tys, J. Tys, Ac. Agroph. 13, (3) (2009)

3. J. Bień, M. Zabochnicka-Świątek, L. Sławik, Inż. i Ochr. Środ. 13, (3) (2010)

4. G. Jard, C. Dumas, J.P. Delgenes, H. Marfaing, B. Sialve, J.P. Steyer, H. Carrčre, Biochem. Eng. Jour. 79 (2013)

5. Y. N. Barbot, H. M. Falk, R. Benz, J. Appl. Phycol. 27 (2015)

6. Y. N. Barbot, L. Thomsen, R. Benz, Mar. Drugs 13 (2015)

7. M. Dębowski, A. Grala, M. Zieliński, M. Dudek, Archiv. of Environmental Protection 38, (4) (2012)

8. T. Kobayashi, Y.-P. Wu, Z.-J. Lu, K.-Q. Xu, Energies 8 (2015)

9. W. W. Carmichael, Świat Nauki 3 (1994)

10. B. Rakowska, M. Sitkowska, E. Szczepocka, B. Szulc, Ocean. and Hydrobiol. Stud. 34, (1) (2005)

11. H. Bucka, E. Wilk-Woźniak,Glony pro- $i$ eukariotyczne zbiorowisk fitoplanktonu $w$ zbiornikach wodnych Polski Poludniowej (Instytut Ochrony Przyrody - PAN, Kraków, 2007)

12. I. Michalak, R. Wilk, K. Chojnacka, Waste Biom. Valor. 8 (2017)

13. I. Sanseverino, D. Conduto, L. Pozzoli, S. Dobricic, T. Lettieri, Algal bloom and its economic impact (JRC Technical Reports, 2016)

14. N. Wasmund, Harmful algal blooms in coastal waters of the south-eastern Baltic Sea. In: G. Schernewski et al., Baltic Coastal Ecosystems (Springer-Verlag Berlin Heidelberg, 2002)

15. M. Koyama, S. Yamamoto, K. Ishikawa, S. Ban, T. Toda, Ecol. Eng. 69 (2014)

16. L. Håkanson, A. C. Bryhn, Controlling Eutrophication in the Baltic Sea and the Kattegat. In. A. A. Ansari et al. (eds.) Eutrophication:
Causes, Consequences and Control (Springer Science+Business Media B.V., 2011)

17. E. Jachniak, Wpływ czynników fizykochemicznych oraz hydrologicznych na przebieg procesów eutrofizacyjnych $w$ wybranych zbiornikach zaporowych potudniowej Polski, Praca doktorska (Uniwersytet Rolniczy, Kraków, 2010)

18. K. Szoszkiewicz, S. S. Jusik, T. Zgoła, Klucz do oznaczania makrofitów dla potrzeb oceny stanu ekologiczmego wód powierzchniowych (Biblioteka Monitoringu Środowiska, Warszawa 2010)

19. V. Vivekanand, V. G. H. Eijsink, S. J. Horn, J. Appl. Phycol. 24 (2012)

20. S. Tedesco, K.Y. Benyounis, A.G. Olabi, Energy 61 (2013)

21. I. Angelidaki, M. Alves, D. Bolzonella, L. Borzacconi, L. Campos, A. Guwy, S.V. Kalyuzhnyi, P. Janicek, J.B. Van Lier, Water Sci. Technol. 59 (2009)

22. W. Braune, M. D. Guiry, A colour guide to common benthic green, brown and red algae of the world's oceans (Königstein: Koeltz Scientific Books, 2011)

23. D.M. John, The Freshwater Algal Flora of the British Isles: An Identification Guide to Freshwater and Terrestrial Algae, Tom 1, (Cambridge University Press, 2002)

24. M. Leśniewska, M. Witak, Ocean. and Hydrobiol. Stud. Intern. Jour. of Oceanography and Hydrobiology 40, (1) (2011)

25. M. Kesaano, Sustainable Management of Duckweed Biomass Grown for Nutrient Control in Municipal Wastewaters. All Graduate Theses and Dissertations, (Utah State University, DigitalCommons@USU 2011)

\section{Web pages:}

http://www.algaebase.org/search/species/detail/?specie s_id=291

http://www.hel.univ.gda.pl/atlas/organizmy.htm http://www.hel.univ.gda.pl/

http://ccba.ug.edu.pl/pages/pl/strona-glowna.php 